\title{
KERAGAAN TEKNIS JTEDS PADA ALAT TANGKAP ARAD DI PEKALONGAN
}

\author{
Tri Wahyu Budiarti dan Mahiswara \\ Peneliti pada Balai Riset Perikanan Laut, Muara Baru-Jakarta \\ Teregistrasi I tanggal: 15 Agustus 2007; Diterima setelah perbaikan tanggal: 9 Januari 2008; \\ Disetujui terbit tanggal: 14 April 2009
}

\begin{abstract}
ABSTRAK
Peningkatan kebutuhan dasar hidup para nelayan di Pekalongan menyebabkan mereka mengembangkan alat tangkap serupa mini bottom seine (arad). Hal ini dapat mengganggu kelangsungan hidup sumber daya ikan di masa mendatang karena banyaknya hasil tangkapan sampingan ikan berukuran kecil yang belum layak tangkap. Menyikapi hal tersebut, telah dilakukan uji coba alat pereduksi ikan muda dan sampah dengan alat tangkap tangkap arad yang menggunakan perangkat JTEDs (Juvenile and Trash Excluder Devices) yang diopersikan dengan menggunakan kapal nelayan berdimensi 8,80 m panjang, 2,80 m lebar dan 1,10 $\mathrm{m}$ dalam di perairan utara Pekalongan pada akhir Juli 2006. Sebagai perlakuan digunakan JTEDs dengan lebar kisi-kisi 17,5 $\mathrm{mm}$ dengan bagian atasnya dibuat terbuka dan diberi cover net berbentuk kantong untuk menampung ikan yang lolos. Rata-rata hasil tangkapan ikan dalam condend adalah $5.774 \mathrm{~kg}$ dengan variasi total tangkapan per stasiun $2.630-10.250 \mathrm{~kg}$. Rata-rata ikan yang masuk cover net adalah $10.241 \mathrm{~kg}$ dengan variasi total tangkapan per stasiun $5.640-14.340 \mathrm{~kg}$. Hasil tangkapan dalam cover net menunjukkan bahwa ikan-ikan yang lolos tergolong ikan muda dan berukuran kecil. Selektivitas arad untuk ikan kuniran (Upenus sulphureus), petek (Leiognathus splenden dan L. decorus) masingmasing terjadi pada ukuran panjang $89,17 \mathrm{~mm}$ dan $(67,43$ dan $67,47 \mathrm{~mm})$.
\end{abstract}

\section{KATAKUNCl: $\quad$ bottom seine net, arad, JTEDs, selektivitas, cover net, condend, Pekalongan}

\section{ABSTRACT: Technical performance of JTEDs on mini bottom seine net in Pekalongan}

The increase of basic live need of fishers in Pekalongan causes them to develop a gear like mini bottom seine (arad). This gear might disturb survival of fish resource in the future because of a large number of juvenile and trash fish caught. Therefore, the experiment on gear reducer for juvenile and by catch as well using JTEDs (Juvenile and Trash Excluder Devices) set in mini bottom seine operated by fisher's fishing vessel with dimension size of $8.80 \mathrm{~m}$ in length, $2.80 \mathrm{~m}$ in body wide and 1.10 in depth, respectively was carried out on end of July 2006 in east coast water of Pekalongan. The treatment was JTEDs having $17.5 \mathrm{~mm}$ in grid equipped by cover net on the top side to hold small fish (juvenile) caught. The juvenile catch in the cod end averaged $5774 \mathrm{~kg}$ with variation from all stations of $5,640-14,340 \mathrm{~kg}$. Total catch in cover net showed that un-seined fish was juvenile having small size. Selectivity of mini bottom seine (arad) for kuniran (Upenus sulphureus), petek (Leiognathus splenden and L. decorus) was observed for their total length of $89.17 \mathrm{~mm}, 67.43$ and 67.47, respectively.

\section{KEYWORDS: bottom seine net, arad, JTEDs, selektivity, cover net, condend, Pekalongan}

\section{PENDAHULUAN}

Perairan Pekalongan adalah salah satu penghasil ikan terbanyak di wilayah perairan utara Jawa Tengah. Peningkatan jumlah nelayan serta kebutuhan pangan telah mendorong nelayan di daerah Pekalongan mengembangkan alat tangkap arad, yaitu alat tangkap yang serupa dengan mini bottom seine net.

Selain menangkap ikan berukuran besar yang telah dewasa dan mempunyai nilai ekonomis di pasaran, alat tangkap arad juga menangkap ikan muda-yuwana (juvenile) dan ikan rucah (trash fish) yang bernilai ekonomis rendah. Juvenile dan trash fish seperti ubur-ubur, bintang laut, dan kekerangan yang ikut tertangkap arad dibuang kembali ke laut dalam keadaan mati dan diistilahkan sebagai discards (buangan). Buangan ini baik berupa hasil tangkap sampingan maupun udang yang berada di bawah ukuran (under sized) menyebabkan dampak buruk terhadap keseimbangan lingkungan maupun sumber daya ikan (Pascoe, 1997).

Untuk mengatasi hal tersebut, Balai Riset Perikanan Laut telah melakukan uji coba alat pereduksi ikan muda dan rucah pada mini bottom trawl. Penelitian uji coba penangkapan dilakukan melalui penggunaan perangkat JTEDs pada alat tangkap arad yang dilakukan di perairan utara Jawa. Alat pereduksi ikan muda dan rucah yang diuji 

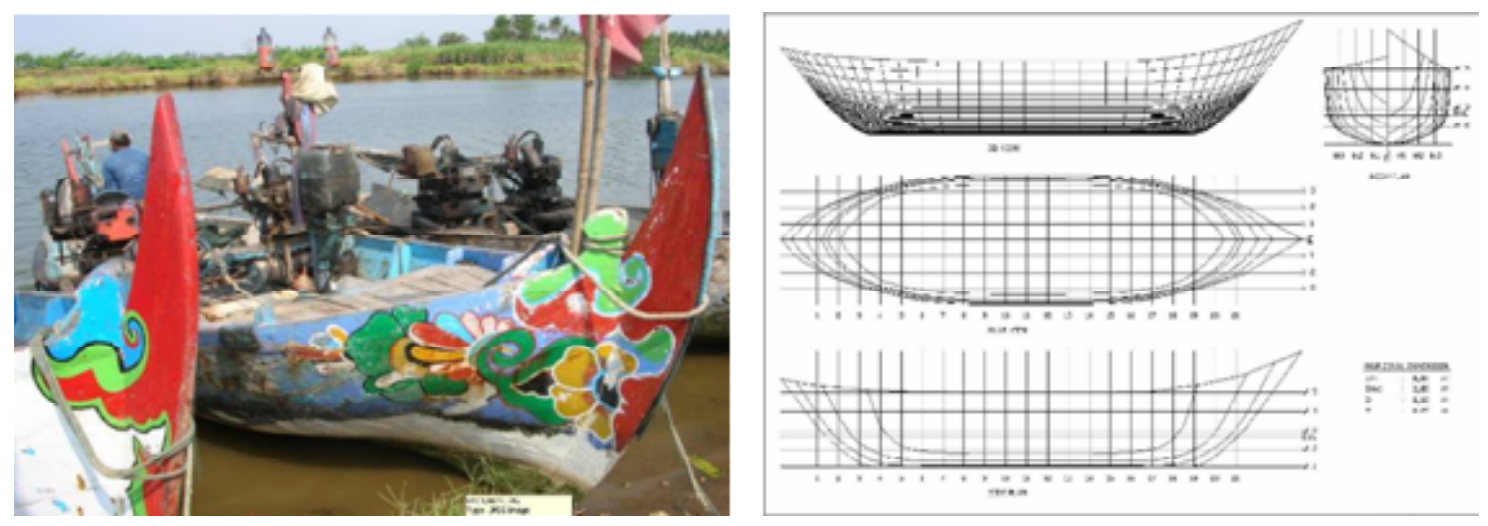

Gambar 1. Perahu dan bentuk rencana garis perahu arad yang digunakan untuk uji coba.

Figure 1. Fishing boat of arad and its lines plan used in the experiment.

cobakan merupakan hasil temuan peneliti SEAFDECThailand yang telah dimodifikasi dan disesuaikan dengan alat tangkap yang dioperasikan di Indonesia. Selanjutnya, Balai Riset Perikanan Laut tidak merubah nama JTEDs menjadi nama lain sebagai obyek penelitiannya, karena dianggap telah memenuhi kriteria baik desain, konstruksi maupun fungsinya, dan mudah diingat.

Pada tahun 2005 telah diujicobakan JTEDs di perairan Pekalongan dengan menggunakan 3 macam perlakuan, yaitu JTEDs dengan lebar kisi-kisi 10,0; 17,5; dan 25,4 mm. Ketiga jenis perlakuan jaring tersebut dioperasikan pada kedalaman yang sama yaitu 10-40 m. Pada uji coba JTEDs dengan menggunakan 3 perlakuan ini masing-masing meloloskan ikan kecil dan rucah 2,42-40,18\%; 9,47$63,45 \%$; dan $4,65-26,05 \%$ dari total ikan yang tertangkap, berturut-turut untuk lebar kisi-kisi 10,0; 17,5; dan 25,4 mm. Berdasarkan pada hasil uji coba tahun 2005 tersebut, JTEDs dengan ukuran lebar kisi $17,5 \mathrm{~mm}$ merupakan perlakuan yang paling sesuai dan efektif untuk perairan Pekalongan, karena mempunyai persentase pelolosan ikan kecil dan rucah yang paling tinggi dibandingkan dengan 2 perlakuan lain. Langkah lanjut dari penelitian ini adalah digunakannya JTEDs dengan lebar kisi $17,5 \mathrm{~mm}$ sebagai bahan ujicoba penelitian pada tahun 2006 . Tujuan penelitian ini adalah untuk memperoleh informasi produktivitas dan selektivitas alat tangkap arad yang dilengkapi JTEDs dengan lebar kisi 17,5 $\mathrm{mm}$.

\section{BAHAN DAN METODE}

\section{Bahan dan Alat}

Kegiatan uji coba dilakukan dengan menggunakan kapal nelayan berdimensi panjang (Loa) $8,80 \mathrm{~m}$, lebar (B) 2,80 $\mathrm{m}$ dan dalam (D) $1,10 \mathrm{~m}$ dengan dilengkapi mesin diesel Dongfeng 20 HP (Gambar 1).
Alat tangkap yang digunakan adalah jaring arad dengan dimensi tali ris atas (head rope): $24 \mathrm{~m}$, tali ris bawah (ground rope): $27 \mathrm{~m}$, dan diameter mata jaring bagian kantong 0,75 inci, menggunakan 15 buah pelampung y-8 dan 1 buah pelampung bola diameter 6" (Gambar 2). Jaring arad ini dilengkapi dengan alat pereduksi ikan muda dan rucah (JTEDs).

JTEDs yang digunakan adalah tipe semicurve dari SEAFDEC yang telah dimodifikasi yaitu disesuaikan dengan ukuran jaring traw/ yang digunakan. JTEDs dipasang pada bagian antara badan dan kantong jaring (Gambar 3).

JTEDs yang diujicobakan menggunakan kisi-kisi besi yang berukuran $17,5 \mathrm{~mm}$ yang bagian atasnya dibuat terbuka dan diberi cover net berupa jaring knotless dengan ukuran mata $5 \mathrm{~mm}$ yang berbentuk kantong. Diharapkan ikan yang berukuran relatif kecil (juvenile) atau ikan muda dan rucah tidak masuk ke kantong jaring (codend) tetapi akan lolos keluar melalui bagian atas JTEDs yang terbuka dan akan tertampung di dalam cover net (Gambar 4).

\section{Waktu dan Lokasi Penelitian}

Penelitian dan uji coba dilakukan pada akhir bulan Juli 2006-awal Agustus 2006 di perairan utara Pekalongan, Jawa Tengah. Kegiatan penangkapan dilakukan pada pagi-sore hari di perairan utara Pekalongan pada kedalaman 20-45 m (Gambar 5).

Lokasi penangkapan pada posisi geografis sekitar (06³7’540" S-06²8'286" S)-(10941'098" E$\left.109^{\circ} 47^{\prime} 313^{\prime \prime} \mathrm{E}\right)$, dengan lama penarikkan jaring berkisar 2-3 jam dan kecepatan kapal 2 knot. Uji coba JTEDs dilakukan pada 11 stasiun, tetapi hasil tangkapan yang dianalisis hanya 10 stasiun, karena terjadi kerusakkan mesin saat towing pada stasiun 9. Posisi penangkapan tercantum pada Tabel 1. 


\section{Metode Pengumpulan Data}

Data dan informasi terkait dengan aspek selektivitas alat tangkap arad diperoleh dengan melakukan uji coba arad yang dilengkapi alat pereduksi ikan muda dan rucah (JTEDs). Hasil tangkapan kemudian dipisahkan berdasarkan pada jumlah ikan yang masuk ke kantong jaring (codend) dan yang masuk ke bagian covernet JTEDs untuk kemudian didentifikasi, ditimbang, dihitung lalu dicatat, dan untuk ikan yang dominan diukur (panjang, tebal, dan bobotnya). Identifikasi jenis ikan mengacu pada referensi Fischer \& Whitehead (1974).

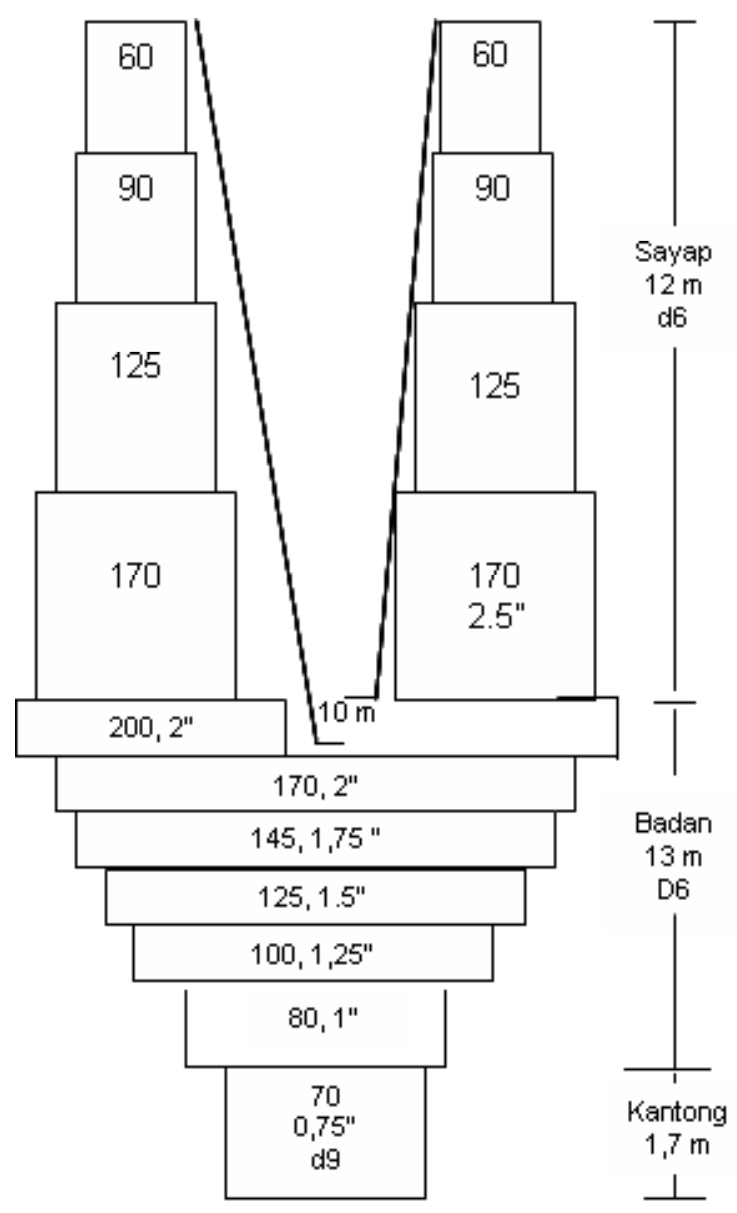

Gambar 2. Desain arad yang digunakan untuk ujicoba JTEDs.

Figure 2. Design of arad used in the experiment.
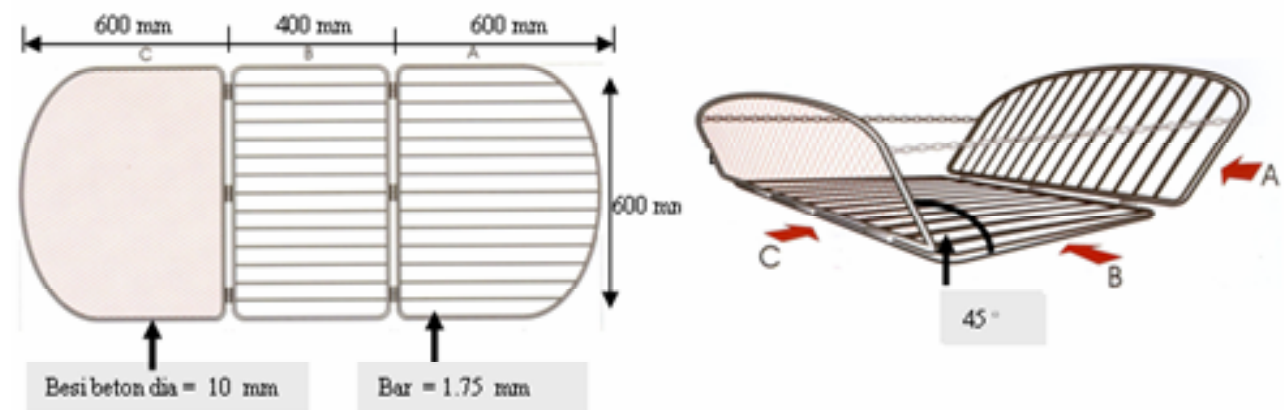

45

Gambar 3. Desain JTEDs yang diujicobakan.

Figure 3. Design of JTEDs used in the experiment. 


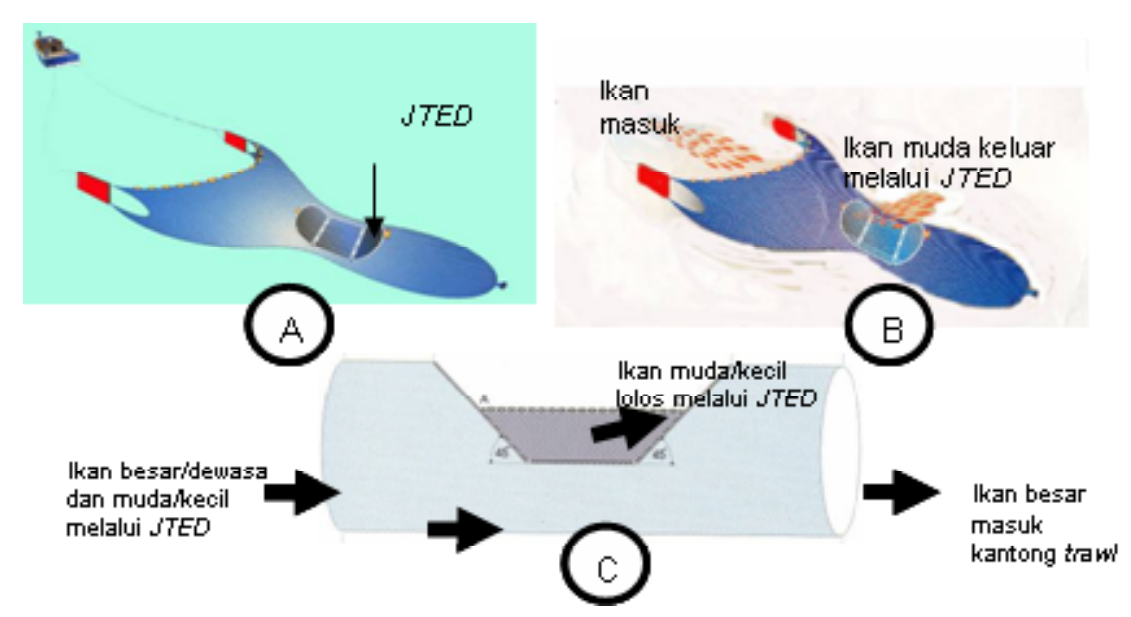

Gambar 4. Posisi pemasangan JTEDs pada trawl (A) dan prinsip kerja JTEDs diilustrasikan seperti Gambar (B) dan (C).

Figure 4. Position of JTEDs on trawl (A), mechanism of JTEDs Illustrated on (B) and (C).

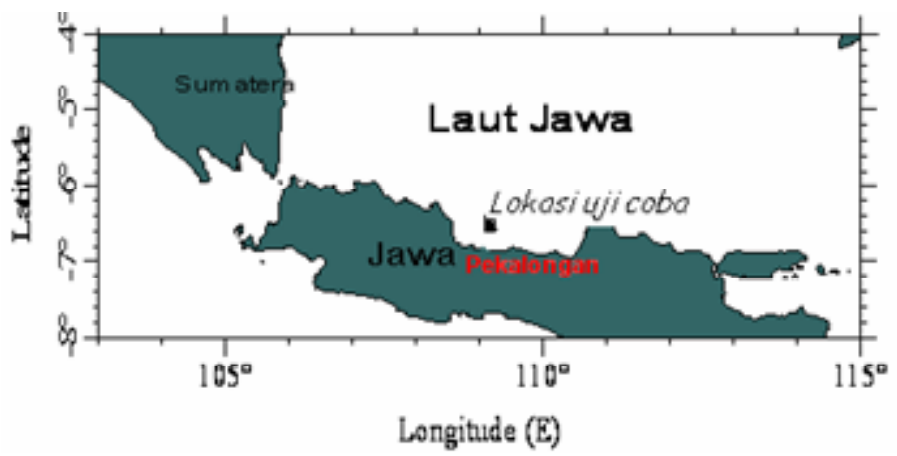

Gambar 5. Lokasi uji coba JTEDs.

Figure $5 . \quad$ Location of the experimental fishing using JTEDs.

Tabel 1. Posisi penangkapan

Table 1. Position of fishing operation

\begin{tabular}{|c|c|c|c|c|c|c|}
\hline $\begin{array}{c}\text { Stasiun/ } \\
\text { Station }\end{array}$ & $\begin{array}{l}\text { Jam setting/ } \\
\text { Time setting }\end{array}$ & $\begin{array}{l}\text { Posisi/ } \\
\text { Position }\end{array}$ & Haluan & Speed & $\begin{array}{l}\text { Jam hauling/ } \\
\text { Time hauling }\end{array}$ & $\begin{array}{c}\text { Posisi/ } \\
\text { Position }\end{array}$ \\
\hline \multirow[t]{2}{*}{1} & 7.38 & S 06운 & $20^{\circ}$ & 2 knot & 9.52 & S 063, $415^{\prime}$ \\
\hline & & E $109^{\circ} 41,199^{\prime}$ & & & & E $109^{\circ} 42,291^{\prime}$ \\
\hline 2 & 10.30 & $\begin{array}{l}\text { S 0637,540' } \\
\text { E 10941,997' }\end{array}$ & $200^{\circ}$ & $2 \mathrm{knot}$ & 12.51 & $\begin{array}{l}\text { S 06 } 41,680^{\prime} \\
\text { E 109 } 41,480^{\prime}\end{array}$ \\
\hline \multirow[t]{2}{*}{3} & 7.08 & S 06눈, $163^{\prime}$ & $20^{\circ}$ & 2 knot & 9.19 & S $06^{\circ} 44,057^{\prime}$ \\
\hline & & E 10944,706' & & & & E 109 46,730' \\
\hline 4 & 10.25 & $\begin{array}{l}\text { S 064, } 457^{\prime} \\
\text { E 10941 } 997^{\prime}\end{array}$ & $240^{\circ}$ & $2 \mathrm{knot}$ & 12.50 & $\begin{array}{l}\text { S 06 } 47,722 \\
\text { E } 109^{\circ} 41,365^{\prime}\end{array}$ \\
\hline 5 & 6.45 & 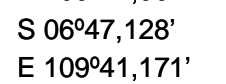 & $70^{\circ}$ & 2 knot & 9.45 & $\begin{array}{l}\text { S } 06^{\circ} 48,286^{\prime} \\
\text { E } 109^{\circ} 39,331^{\prime}\end{array}$ \\
\hline 6 & 7.42 & $\begin{array}{l}\text { S 0641,813' } \\
\text { E 1094, } 189^{\prime}\end{array}$ & $280^{\circ}$ & $2 \mathrm{knot}$ & 10.00 & $\begin{array}{l}\text { S 06 } 40,271^{\prime} \\
\text { E } 109^{\circ} 40,577^{\prime}\end{array}$ \\
\hline 7 & 11.20 & $\begin{array}{l}\text { S 064, } 460^{\prime} \\
\text { E 109² } \\
\end{array}$ & $240^{\circ}$ & $2 \mathrm{knot}$ & 14.00 & $\begin{array}{l}\text { S 06 } 46,887^{\prime} \\
\text { E 109 } 40,792^{\prime}\end{array}$ \\
\hline 8 & 7.55 & 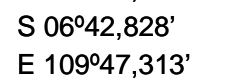 & $15^{\circ}$ & $2 \mathrm{knot}$ & 10.32 & $\begin{array}{l}\text { S 06ㅇ } 38,958^{\prime} \\
\text { E } 109^{\circ} 46,919^{\prime}\end{array}$ \\
\hline 9 & \multicolumn{6}{|c|}{ Terjadi kerusakkan mesin penarik } \\
\hline 10 & 6.33 & $\begin{array}{l}\text { S 064, } 741^{\prime} \\
\text { E 109웅,862' }\end{array}$ & $35^{\circ}$ & 2 knot & 9.35 & $\begin{array}{l}\text { S } 06^{\circ} 46,691^{\prime} \\
\text { E } 109^{\circ} 38,420^{\prime}\end{array}$ \\
\hline 11 & 7.12 & $\begin{array}{l}\text { S 0643,995' } \\
\text { E 10941,098' }\end{array}$ & $10^{\circ}$ & $2 \mathrm{knot}$ & 10.19 & $\begin{array}{l}\text { S 06 } 44,413^{\prime} \\
\text { E 109 } 41,086^{\prime}\end{array}$ \\
\hline
\end{tabular}




\section{Analisis Data}

Selektivitas alat tangkap adalah fungsi alat tangkap untuk menangkap ikan yang terbatas pada jenis dan ukuran ikan tertentu pada suatu populasi yang ditemui di daerah penangkapan atau status populasi (Arimoto, 1999; Ferno \& Steiner, 1994). Kurva selektivitas dihitung berdasarkan pada model logistik (Sparre \& Venema, 1989) sebagai berikut:

$$
S(I)=1 /[1+\exp (a . I+b)]
$$

di mana:

$a$ dan $b=$ parameter kurva logistik

Parameter ini dihitung dengan metode kuadrat terkecil menggunakan Solverpada program Microsoft Excel.

\section{HASIL DAN BAHASAN}

\section{Produktivitas}

Hasil tangkapan total pada 10 stasiun diperoleh $160,15 \mathrm{~kg}$ atau rata-rata hasil tangkapan per tawur $16,15 \mathrm{~kg}$. Variasi tangkapan yang masuk codend berkisar 2,63-10,25 kg dengan total tangkapan 57,74 kg. Laju tangkap rata-rata $36,1 \%$ dari laju tangkap rata-rata jika jaring tidak dilengkapi JTEDs.
Sedangkan variasi tangkapan yang masuk cover net berkisar 5,64-14,34 kg dengan total tangkapan 102,41 $\mathrm{kg}$, laju tangkap menunjukkan $63,9 \%$ dari rata-rata laju tangkap jika jaring tidak dilengkapi JTEDs (Tabel 2). Laju tangkap ikan yang masuk codend dan lolos cover net tercantum pada Tabel 3.

Jenis ikan yang berhasil ditangkap 68 jenis antara lain ikan beloso (Saurida sp.), kuniran (Upeneus sulphureus), kurisi (Nemipterus perorili), petek (Leiognathus sp.), dan biota invertebrata lainnya.

\section{Ukuran Ikan}

Hasil pengukuran terhadap panjang, tebal, dan bobot ikan contoh yang dominan tertangkap (Upeneus sulphureus, Leiognathus splendens, Leiognathus decorus) terlihat pada Tabel 4. Ukuran ikan dibedakan antara ikan yang masuk kantong jaring trawl (codend) dan jaring pembungkus JTEDs (cover net). Gambar 6 menunjukkan bahwa rata-rata ukuran ketiga ikan contoh dominan dengan menggunakan JTEDs kisikisi $17,5 \mathrm{~mm}$ yang lolos atau masuk cover net cenderung berukuran lebih kecil dibandingkan dengan rata-rata ukuran ikan yang masuk kantong (codend). Ukuran Leiognathus decorus yang masuk kantong (codend) dan yang lolos cover net tidak menunjukkan perbedaan.

Tabel 2. Hasil tangkapan di codend dan cover net

Table 2. Catch in codend and cover net

\begin{tabular}{|c|c|c|c|c|c|}
\hline \multirow{2}{*}{ Stasiun } & \multicolumn{2}{|c|}{ Tangkapan/ Catch $(\mathbf{k g})$} & \multirow{2}{*}{ Stasiun } & \multicolumn{2}{|c|}{ Tangkapan/ Catch $(\mathbf{k g})$} \\
\hline & Codend & Covernet & & Codend & Covernet \\
\hline 1 & 7,545 & 8,51 & 7 & 5,89 & 11,81 \\
\hline 2 & 10,25 & 10,26 & 8 & 7,43 & 14,34 \\
\hline 3 & 3,2 & 9,38 & 10 & 2,77 & 5,64 \\
\hline 4 & 4,43 & 12,32 & 11 & 5,795 & 10,28 \\
\hline 5 & 2,63 & 7,11 & Rata-rata & 5,774 & 10,241 \\
\hline 6 & 7,8 & 12,76 & Total & 57,74 & 102,41 \\
\hline
\end{tabular}

Tabel 3. Laju tangkap ikan yang masuk codend dan lolos cover net Table 3. Codend and cover net catch rate

\begin{tabular}{|c|c|c|c|c|c|c|c|}
\hline \multirow[t]{2}{*}{ Stasiun } & \multicolumn{2}{|c|}{$\begin{array}{c}\text { Laju tangkap/ } \\
\text { Catch rate (kg/jam) }\end{array}$} & \multirow[t]{2}{*}{ Towing (jam) } & \multirow[t]{2}{*}{ Stasiun } & \multicolumn{2}{|c|}{$\begin{array}{c}\text { Laju tangka/ } \\
\text { Catch rate } \mathrm{p}(\mathrm{kg} / \mathrm{jam})\end{array}$} & \multirow[t]{2}{*}{ Towing (jam) } \\
\hline & Codend & Covernet & & & Codend & Covernet & \\
\hline 1 & 3,018 & 3,404 & 2,5 & 7 & 2,265 & 4,542 & 2,6 \\
\hline 2 & 4,100 & 4,104 & 2,5 & 8 & 2,972 & 5,736 & 2,5 \\
\hline 3 & 1,455 & 4,264 & 2,2 & 10 & 0,923 & 1,880 & 3 \\
\hline 4 & 1,772 & 4,928 & 2,5 & 11 & 1,932 & 3,427 & 3 \\
\hline 5 & 0,877 & 2,370 & 3 & Rata-rata & 2,3 & 4,0 & 2,6 \\
\hline 6 & 3,250 & 5,317 & 2,4 & Total & 22,6 & 40,0 & 26,2 \\
\hline
\end{tabular}




\section{Selektivitas JTEDs}

Perbandingan antara ikan yang lolos (masuk cover net) dan tertangkap (masuk codend) pada uji coba JTEDs di perairan Pekalongan adalah 63,9:36,1. Hal ini menunjukkan bahwa secara kuantitas terjadi penurunan hasil tangkapan pada penggunaan arad yang dilengkapi JTEDs. Pada penggunaan arad yang dilengkapi JTEDs terjadi penurunan produksi $63,9 \%$, jika dibandingkan dengan arad yang tidak dilengkapi JTEDs. Tetapi jika dilihat dari jenis dan ukuran ikan yang lolos, sebenarnya sebagian besar ikan yang lolos berukuran lebih kecil dibandingkan ikan yang tertangkap.

Hasil analisis berdasarkan pada panjang cagak (fork length) terhadap 3 jenis ikan dominan (Upeneus sulphureus, Leiognathus splenden, dan Leiognathus Decorus) yang berhasil lolos dari ikan yang tertangkap dapat dilihat pada Tabel 5, 6, dan 7. Persentase ikan kuniran yang lolos (masuk cover net) paling besar adalah ikan dengan ukuran panjang $\mathrm{FL} 5,5 \mathrm{~cm}$, yaitu $42 \%$ dari total ikan yang lolos. Panjang maksimal yang lolos adalah $9,5 \mathrm{~cm}$. Sedangkan persentase terbesar ikan yang tertangkap (masuk codend) berada pada ikan dengan ukuran panjang $9 \mathrm{~cm}$, yaitu $78 \%$ dari total ikan yang tertangkap (Tabel 5).
Tabel 6 menunjukkan bahwa persentase terbesar ikan petek yang lolos (masuk cover net) terjadi pada ikan dengan ukuran panjang $\mathrm{FL} 6 \mathrm{~cm}$ yaitu $49 \%$ dari total ikan yang lolos. Ukuran panjang maksimal yang dapat lolos $7,5 \mathrm{~cm}$. Sedangkan persentase terbesar ikan yang tertangkap (masuk codend) memiliki ukuran panjang $6,5 \mathrm{~cm}$ yaitu $32 \%$ dari total yang tertangkap.

Tabel 7 menunjukkan bahwa persentase ikan petek yang lolos (masuk cover net) paling besar terjadi pada ikan dengan ukuran panjang $\mathrm{FL} 7 \mathrm{~cm}$, yaitu $32 \%$ dari total ikan yang lolos. Ukuran panjang maksimal yang dapat lolos adalah $9 \mathrm{~cm}$. Persentase terbesar ikan yang tertangkap (masuk codend) berada pada ikan dengan ukuran panjang $8 \mathrm{~cm}$, yaitu $37 \%$ dari total yang tertangkap. Menurut Mahiswara et al. (2004), semakin kecil jarak kisi, maka jumlah hasil tangkapan sampingan yang dikeluarkan akan semakin banyak. Jarak kisi yang lebih besar meningkatkan kisaran ukuran panjang ikan (ke arah lebih besar) yang masuk ke dalam kantong trawl. Hal ini mengakibatkan ikan yang terseleksi untuk keluar dari trawl cenderung terbatas pada kelompok ukuran besar. Selektivitas kisi dapat diekspresikan sebagai fungsi dari panjang ikan dengan jarak antar kisi, dan dapat dianalisis dengan cara menggunakan metode analisis selektivitas mata jaring (Tokai, 1998).

Tabel 4. Ukuran panjang (fork length/FL), tebal, dan bobot ikan dominan

Tabel 4 . Fork length (FL), width, and weight of dominant fishes

\begin{tabular}{clcccc}
\hline No. & Spesies & FL $(\mathbf{c m})$ & Tebal/Widht $\mathbf{( c m )}$ & Bobot/Weight $\mathbf{( g )}$ & n \\
\hline & Cover net & 7,09 & & & \\
1. & Upeneus sulphureus & 6,25 & 0,98 & 13,54 & 65 \\
2. & Leiognathus splendens & 7,62 & 1,00 & 8,87 & 70 \\
3. & Leiognathus decorus & & 12,96 & 73 \\
& Codend & 9,00 & 1,27 & & \\
1. & Upeneus sulphureus & 6,75 & 1,068 & 20,37 & 27 \\
2. & Leiognathus splendens & 7,67 & 1,09 & 12,7 & 50 \\
3. & Leiognathus decorus & & & 9,80 & 30 \\
\hline
\end{tabular}
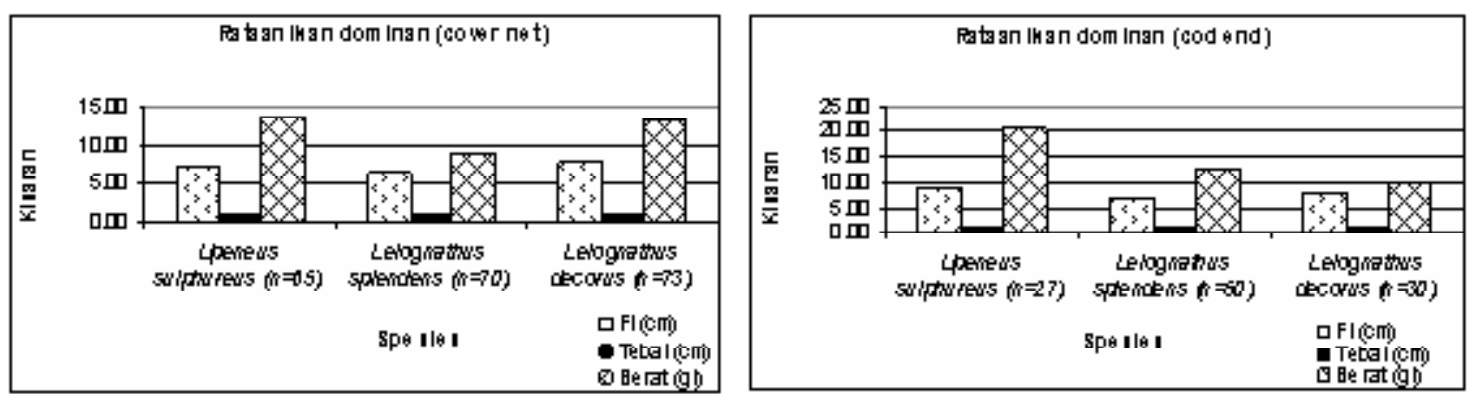

Gambar 6. Figure 6.

Kisaran rata-rata ukuran fork length, tebal, dan bobot ikan dominan. The average of fork length, width, and weight of dominant fish. 
Tabel 5.

Persentase fork length (FL) ikan kuniran yang masuk codend dan lolos cover net

Tabel 5 .

Fork length (FL) percentage of codend and cover net for Upeneus sulphureus

\begin{tabular}{|c|c|c|c|c|c|c|c|c|c|c|c|c|c|}
\hline \multirow{2}{*}{ FL } & \multicolumn{3}{|c|}{ Codend } & \multicolumn{3}{|c|}{ Cover net } & \multirow{2}{*}{$\mathbf{F L}$} & \multicolumn{3}{|c|}{ Codend } & \multicolumn{3}{|c|}{ Cover net } \\
\hline & $\mathbf{n}$ & $(\%)$ & $\%$ kumulatif & $\mathbf{n}$ & (\%) & $\%$ kumulatif & & $\mathbf{n}$ & (\%) & $\%$ kumulatif & $\mathbf{n}$ & (\%) & $\%$ kumulatif \\
\hline 5,5 & & 0 & 0 & 27 & 42 & 42 & 8,5 & 4 & 15 & 15 & 9 & 14 & 74 \\
\hline 6 & & 0 & 0 & 7 & 11 & 52 & 9 & 21 & 78 & 93 & 15 & 23 & 97 \\
\hline 6,5 & & 0 & 0 & 1 & 2 & 54 & 9,5 & 1 & 4 & 96 & 2 & 3 & 100 \\
\hline 7 & & 0 & 0 & 2 & 3 & 57 & 10 & 1 & 4 & 100 & & & \\
\hline 8 & & 0 & 0 & 2 & 3 & 60 & & 27 & & & 65 & & \\
\hline
\end{tabular}

Tabel 6 .

Persentase fork length (FL) ikan petek yang masuk codend dan lolos cover net Tabel 6. Fork length (FL) percentage for Leiognathus splenden entering in codend and cover net

\begin{tabular}{|c|c|c|c|c|c|c|}
\hline \multirow{2}{*}{ FL } & \multicolumn{3}{|c|}{ Codend } & \multicolumn{3}{|c|}{ Cover net } \\
\hline & $\mathbf{n}$ & $(\%)$ & $\%$ kumulatif & $\mathbf{n}$ & $(\%)$ & $\%$ kumulatif \\
\hline 5,5 & 2 & 4 & 4 & 7 & 10 & 10 \\
\hline 6 & 14 & 28 & 32 & 34 & 49 & 59 \\
\hline 6,5 & 16 & 32 & 64 & 17 & 24 & 83 \\
\hline 7 & 8 & 16 & 80 & 11 & 16 & 99 \\
\hline 7,5 & 4 & 8 & 88 & 1 & 1 & 100 \\
\hline 8 & 1 & 2 & 90 & & & \\
\hline 8,5 & 2 & 4 & 94 & & & \\
\hline 9 & 2 & 4 & 98 & & & \\
\hline \multirow[t]{2}{*}{10} & 1 & 2 & 100 & & & \\
\hline & 50 & & & 70 & & \\
\hline
\end{tabular}

Tabel 7. Persentase fork length (FL) ikan petek yang masuk codend dan lolos cover net Tabel 7. Fork length ( $F L)$ percentage for Leiognathus decorus entering in codend and cover net

\begin{tabular}{ccccccc}
\hline \multirow{2}{*}{ L } & \multicolumn{2}{c}{ Codend } & \multicolumn{3}{c}{ Cover net } \\
\cline { 2 - 7 } & $\mathbf{n}$ & $\mathbf{( \% )}$ & \% kumulatif & $\mathbf{n}$ & $\mathbf{( \% )}$ & \% kumulatif \\
\hline 6,5 & 0 & 0 & 0 & 1 & 1 & 1 \\
7 & 7 & 23 & 23 & 23 & 32 & 33 \\
7,5 & 10 & 33 & 57 & 20 & 27 & 60 \\
8 & 11 & 37 & 93 & 22 & 30 & 90 \\
8,5 & 0 & 0 & 93 & 4 & 5 & 96 \\
9 & 2 & 7 & 100 & 3 & 4 & 100 \\
\hline
\end{tabular}

Selektivitas ikan kuniran dan petek pada JTEDs dengan lebar kisi $17,5 \mathrm{~mm}$ ditunjukkan pada Gambar 7, 8 dan 9. Kurva selektivitas arad yang dilengkapi JTEDs dengan kisi-kisi 17,5 mm untuk ikan kuniran terlihat pada Gambar 7. Hasil analisis selektivitas menunjukkan bahwa faktor seleksi $50 \%\left(\mathrm{FL}_{50 \%}\right)$ teramati pada ikan kuniran di panjang cagak (fork length) $89,17 \mathrm{~mm}$.

Gambar 8 menunjukkan kurva selektivitas arad yang dilengkapi JTEDs dengan kisi-kisi $17,5 \mathrm{~mm}$ untuk ikan petek. Kurva ini menunjukkan bahwa berdasarkan pada hasil analisis diperoleh faktor seleksi 50\% $\left(\mathrm{FL}_{50 \%}\right)$ untuk ikan petek 67,43 mm.
Sedangkan kurva selektivitas arad yang dilengkapi JTEDs dengan kisi-kisi 17,5 mm untuk ikan petek dapat dilihat pada Gambar 9. Dari hasil analisis selektivitas pada kurva di bawah ini diperoleh faktor seleksi $50 \%\left(\mathrm{FL}_{50 \%}\right)$ untuk ikan petek $67,47 \mathrm{~mm}$. Berdasarkan pada penelitian ini, diperoleh faktor seleksi $50 \%$ pada ikan petek (Leiognathus splenden dan Leiognathus decorus) hampir sama besar. Hal ini dimungkinkan terjadi karena adanya persamaan bentuk dan ukuran tubuh antara kedua jenis petek tersebut.

Hasil penelitian Hufiadi et al. (2008) menunjukkan bahwa faktor seleksi $50 \%\left(\mathrm{FL}_{50 \%}\right)$ adalah untuk ikan 


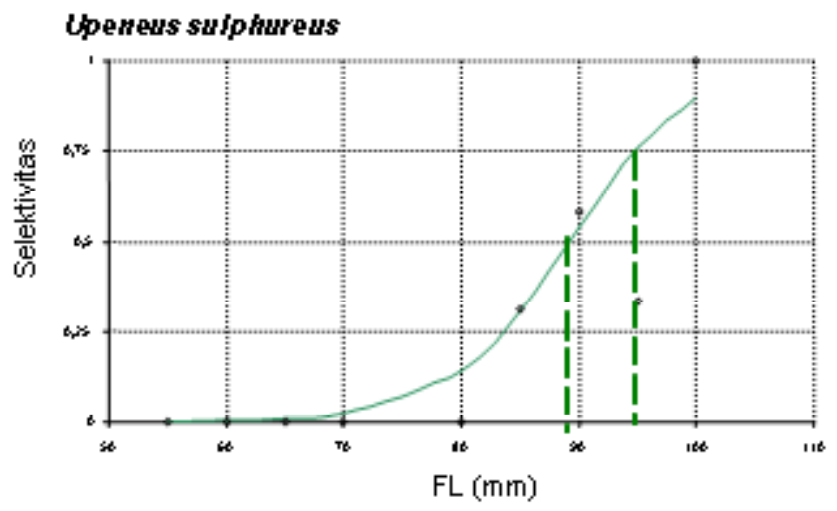

Gambar 7. Kurva selektivitas ikan kuniran yang tertangkap (masuk codend) dan lolos (masuk cover net) pada arad yang dilengkapi JTEDs dengan lebar kisi $17,5 \mathrm{~mm}$.

Figure 7. Selecivity curve of Upeneus sulphureus caught in codend and cover net of arad equipped by JTEDs with $17.5 \mathrm{~mm}$ bar.

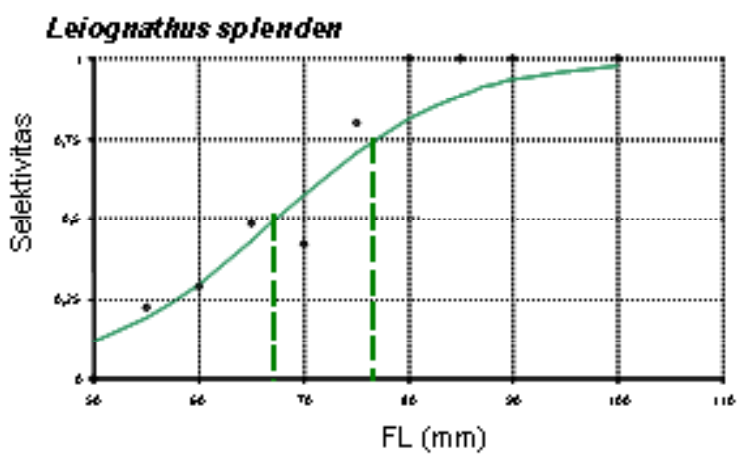

Gambar 8. Kurva selektivitas ikan petek yang tertangkap (masuk codend) dan lolos (masuk cover net) pada arad yang dilengkapi JTEDs dengan lebar kisi $17,5 \mathrm{~mm}$.

Figure 8. Selecivity curve of Leiognathus splenden caught in codend and cover net of arad equipped by JTEDs with $17.5 \mathrm{~mm}$ bar.

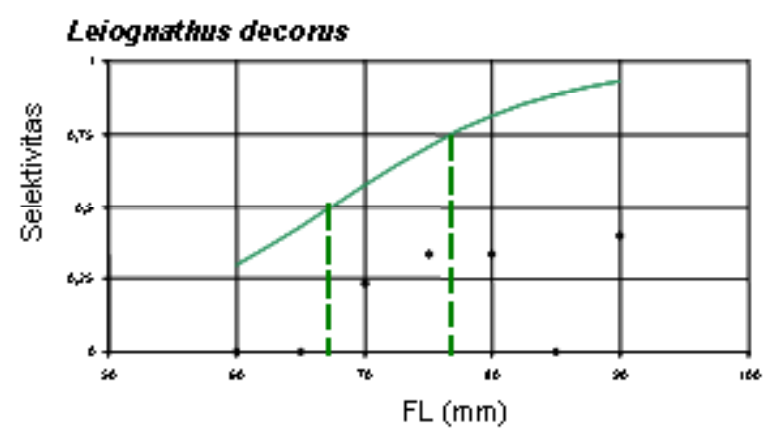

Gambar 9. Kurva selektivitas ikan petek yang tertangkap (masuk codend) dan lolos (masuk cover net) pada arad yang dilengkapi JTEDs dengan lebar kisi $17,5 \mathrm{~mm}$.

Figure 9. Selecivity curve of Leiognathus decorus caught in codend and cover net of arad equipped by JTEDs with $17.5 \mathrm{~mm}$ bar.

kuniran $\mathrm{FL}_{50 \%} 105,78 \mathrm{~mm}$ dan ikan petek $\mathrm{FL}_{50 \%} 94,75$ $\mathrm{mm}$ pada traw/mini yang dilengkapi JTEDs dengan kisi-kisi 17,5 mm yang diujicobakan di perairan utara Jawa. Ukuran $\mathrm{FL}_{50 \%}$ hasil penelitian Hufiadi et al. (2008) mempunyai ukuran yang lebih besar jika dibandingkan dengan ukuran $\mathrm{FL}_{50 \%}$ pada arad dilengkapi JTEDs kisi-kisi 17,5 mm yang diujicobakan di perairan Pekalongan. Beberapa faktor yang diduga berpengaruh terhadap selektivitas kisi antara lain kelenturan tubuh ikan, penutupan atau penyumbatan 
kisi, bentuk tubuh ikan, dan posisi ikan saat menabrak kisi (Mahiswara et al., 2006). Hasil analisis ukuran $\mathrm{FL}_{50 \%}$ ikan kuniran dan ukuran $\mathrm{FL}_{50 \%}$ ikan petek pada penelitian ini mempunyai nilai lebih kecil jika dibandingkan dengan hasil penelitian Hufiadi et al. (2008). Hal ini diduga terjadi karena perbedaan daerah penangkapan (fishing ground) sehingga ada kemungkinan terjadi perbedaan perairan misalnya jumlah sampah yang ada di perairan tersebut. Perbedaan dasar perairan ini menyebabkan penutupan atau penyumbatan kisi oleh sampah. Dengan demikian, penutupan kisi oleh sampah atau ikan hasil tangkapan dapat mengakibatkan ikan ukuran kecil keluar dari jaring trawl.

\section{KESIMPULAN}

1. Total hasil tangkapan ikan dari masing-masing stasiun bervariasi, pada codend berkisar 2,63$10,25 \mathrm{~kg}$, dengan total tangkapan $57,74 \mathrm{~kg}$ atau rata-rata tangkapan $5,774 \mathrm{~kg}$ dan pada covernet berkisar 5,64-14,34 kg dengan total tangkapan $102,41 \mathrm{~kg}$ atau rata-rata tangkapan $10,241 \mathrm{~kg}$.

2. Laju tangkap pada codend berkisar $0,877-4,100$ $\mathrm{kg}$ dengan total tangkapan $22,564 \mathrm{~kg}$ atau ratarata $2,256 \mathrm{~kg}$, sedangkan pada covernet berkisar $1,880-5,736 \mathrm{~kg}$ dengan total tangkapan $39,971 \mathrm{~kg}$ atau rata-rata $3,997 \mathrm{~kg}$.

3. Hasil tangkapan pada covernet menunjukkan bahwa ikan-ikan yang lolos tersebut merupakan ikan yang mempunyai ukuran panjang cagak (fork length) dan tebal tubuh lebih kecil dibandingkan yang masuk codend.

4. Selektivitas $50 \%$ lolosnya ikan kuniran terjadi untuk ikan dengan panjang cagak $\left(\mathrm{FL}_{50 \%}\right)$ 89,17 $\mathrm{mm}$, pada ikan petek (Leiognathus splenden dan Leiognathus decorus) berturut-turut terjadi pada ikan dengan panjang cagak $\left(\mathrm{FL}_{50 \%}\right) 67,43$ dan $67,47 \mathrm{~mm}$.

\section{PERSANTUNAN}

Kegiatan dari hasil riset selektivitas unit penangkapan pukat dasar (bottom seine net) untuk menunjang upaya pemanfaatan sumber daya perikanan yang berkelanjutan, T. A. 2006, di Balai Riset Perikanan Laut-Muara Baru, Jakarta.

\section{DAFTAR PUSTAKA}

Arimoto, T. 1999. Fish for Improving Fish Capture Technology. Tokyo University of Fisheries. Japan.

Ferno, A. \& S. Olsen. 1994. Marine Fish Behaviour in Capture Abundance Estimation. Fishing News Book. London.

Fischer, W. \& P. J. P. Witehead. 1974. FAO Species Identification Sheets for Fishery Purposes. Eastern Indian Ocean (Fishing Area 57) and Western Central Pacific (Fishing Area 71). Rome.

Hufiadi, Mahiswara, \& E. Nurdin. 2008. Selektivitas kisi-kisi juvenile and trash excluder devices pada alat tangkap trawl mini di perairan utara Jawa. Jurnal Penelitian Perikanan Indonesia. 14 (4): 353-361.

Mahiswara, R. I. Wahju, \& D. R. Monintja. 2004. Pengaruh jarak kisi pada turtle excluder devices tipe super shooter terhadap hasil tangkapan sampingan trawl udang. Jurnal Penelitian Perikanan Indonesia. 10 (4): 11-19.

Mahiswara \& R. I. Wahju. 2006. Selektivitas Kisi turtle excluder devices tipe super shooter pada trawl. Jurnal Penelitian Perikanan Indonesia. 12 (1): 2532.

Pascoe, S. 1997. Bycatch Management and the Economic of Discarding. FAO Fisheries Technical Paper No.370. Rome.

Sparre, P. \& S. C Venema. 1999. Introduksi Pengkajian Stok Ikan Tropis Buku 1: Manual. FAO (Diterjemahkan oleh Pusat Penelitian dan Pengembangan Perikanan. Badan Penelitian dan Pengembangan Pertanian. Jakarta).

Tokai, T. 1998. Traw/ with separator panel for bycatch reduction and evaluation methodology of the selective performance. Symposium on Marine Fisheries Beyond the Year 2000. Sustainable Utilization of Fisheries Resources. National Taiwan Ocean University 